\title{
PENGARUH KONSELING ANALISIS TRANSAKSIONAL DALAM MENGENTASKAN MASALAH SISWA YANG TERISOLIR KARENA EGOIS
}

\author{
Muhammad Zainul Wathoni \& Fitri Aulia \\ UniversitasHamzanwadi \\ zainulwathoni@gmail.com \\ Fitriaulia04@gmail.com
}

\begin{abstract}
This study aims to determine the effect of transactional analysis counseling in alleviating problems of students who are isolated due to selfishness in class XI MA Nurul Iman Montong Good school year 2017/2018. This type of research is an experiment with Single Subject Design. The subject of this research was a class XI student. Data collection techniques using student questionnaires isolated because selfish and analyzed by using quantitative data in the form of numbers processed using simple statistics and qualitative data described and processed using narrative analysis. The results showed that the initial condition data of students before being given individual counseling was obtained using isolated questionnaires because they were selfish with a total score of 55 which was included in the isolated category, because they were in the range of 50 to $<65$. Individuals obtained a total score of 42 which was included in the slightly isolated category, because it was in the range of $35 \mathrm{~s} / d<50$. This shows that the Transactional Analysis technique is effective for dealing with the problem of students who are isolated because of selfishness.
\end{abstract}

Keywords: Counseling Transactional Analysis, isolated, selfish

\begin{abstract}
Abstrak
Penelitian ini bertujuan untuk mengetahui pengaruh konseling analisis transaksional dalam mengentaskan masalah siswa yang terisolir karena egois di kelas XI MA Nurul Iman Montong Baik tahun pelajaran 2017/2018. Jenis penelitian ini adalah eksperimen dengan desain penelitian eksperimen Subyek Tunggal (Single Subject Design). Subjek penelitian ini adalah seorang siswa kelas XI IPA. Teknik pengumpulan data menggunakan angket siswa terisolir karena egois dan dianalis dengan menggunakan data kuantitatif berupa angka-angka yang diolah menggunakan statistik sederhana dan data kualitatif dideskripsikan dan diolah menggunakan analisis naratif. Hasil penelitian menunjukkan bahwa data kondisi awal siswa sebelum diberikan konseling individual yang diperoleh menggunakan angket terisolir Karena egois dengan total skor 55 yang termasuk pada kategori terisolir, karena berada pada rentang antara $50 \mathrm{~s} / \mathrm{d}<65$. Pada fase intervensi setelah siswa diberikan treatment layanan konseling individual diperoleh total skor sebesar 42 yang termasuk pada kategori sedikit terisolir, karena berada pada rentang $35 \mathrm{~s} / \mathrm{d}<50$. Hal ini menunjukkan bahwa teknik Analisis Transaksional efektif untuk mengatasi masalah siswa yang terisolir karena egois
\end{abstract}

Kata Kunci: Konseling Analisis Transaksional, terisolir, egois 


\section{PENDAHULUAN}

Terisolir atau biasa disebut dengan dikucilkan atau ditolak oleh temannya merupakan gambaran tentang individu tersebut yang mana seseorang akan terisolir atau ditolak oleh temannya karena sikap dan perilaku individu itu sendiri. Terisolir juga dapat terjadi dikarenakan individu yangegois. Egois atau yang lazim disebut ingin menang sendiri memang merupakan sifat yang tidak baik karena akan mempengaruhi hubungan sosial individu itu sendiri yang mengakibatkan adanya penolakan dari teman disekitarnya.

Siswa terisolir adalah siswa yang mempunyai pengaruh sosial rendah dan penerimaan sosial rendah, sedangkan siswa popular adalah siswa siswa yang memiliki pengaruh sosial dan penerimaan sosial yang tinggi. Graham \& Stuart dalam Sunarya, (2005:21). Adapun ciri anak terisolir menurut Hurlock yaitu: (1) Penampilan diri yang kurang menarik, (2) Kurang sportif, (3) Penampilan yang tidak sesuai dengan standar teman, (4) Perilaku yang menonjolkan diri, mengganggu orang lain, suka memerintah, tidak bekerjasama dan kurang bijaksana, (5) Kurangnya kematangan, terutama kelihatan dalam hal pengendalian emosi, ketenangan, kepercayaan diri dan kebijaksanaan, (6) Mementingkan diri sendiri dan mudah marah, (7) Status sosioekonomis berada di bawah sosioekonomis kelompok, (8) Tempat yang terpencil dari kelompok. (Hurlock, 1980: 217).

Isolasi atau isolate dibagi menjadi dua macam, yaitu voluntary isolate dan involuntary isolate. (1) Voluntary Isolate adalah suatu perbuatan yang menarik diri dari kelompok karena adanya rasa kurang memiliki minat untuk menjadi anggota suatu kelompok. (2) Involuntary Isolate adalah sikap atau perbuatan menolak terhadap orang lain dalam kelompoknya meskipun dia ingin menjadi anggota kelompok tersebut. Involuntary yang subyektif beranggapan bahwa dia tidak dibutuhkan oleh kelompoknya dan menjauhkan diri dari kelompok. (Hurlock, 1980:294).

Konseling mengindikasikan hubungan profesional antara konselor terlatih dengan klien, hubungan yang terbentuk biasanya bersifat individu ke individu. Burk \& Stefflre dalam Latipun (2001). Konseling merupakan aktivitas sosial yang memiliki makna sosial. (Palmer dan McMahon (McLeod). Konseling adalah hubungan pribadi yang dilakukan secara tatap muka antara dua orang, dimana konselor melalui hubungan itu dengan kemampuankemampuan khusus yang dimilikinya, (Tolbert dalam Prayitno, 2004:101).

Analisis Transaksional (AT) adalah psikoterapi transaksional yang dapat digunakan dalam terapi individual, tetapi lebih cocok untuk digunakan dalam terapi kelompok. AT berbeda dengan sebagian besar terapi lain dalam arti ia adalah suatu terapi kontraktual dan desisional. AT melibatkan suatu kontrak yang dibuat oleh klien, yang dengan jelas mengatakan tujuan-tujuan dan arah proses terapi. AT juga berfokus pada putusan-putusan awal yang dibuat oleh klien dan menekankan kemampuan klien untuk membuat putusan-putusan baru. AT menekankan aspekaspek kognitif-rasional-behavioral dan berorientasi kepada penigkatan kesadaran sehingga klien akan mampu membuatputusan-putusan baru dan mengubah cara hidupnya. Corey (1988:159).

Menurut Ian Stewart dan Tony Tilney dalam buku Konseling dan Psikoterapi (Palmer (Ed.)) "Analisis transaksional (AT) (Transactional Analysis) adalah model untuk memahami kepribadian, komunikasi, dan relasi manusia. nama AT didapat pada awalnya model ini digunakan untuk menganalisis pola-pola komunaikasi transaksi yang digunakan orang-orang ketika mereka berelasi dalam pasangan atau kelompok"(2011:569). 
Nelson-Jones (2011: 258) lingkup untuk analisis transaksional berkisar mulai dari lingkungan mirip-rumah ke kantor yang lebih seperti bisnis. Oleh karena isyaratisyarat bahasa tubuh penting dalam melaksanakan analisis transaksional, di kebanyakan kantor trapis tidak ada meja atau kursi yang menghalangi pandangan trapis dank lien terhadap satu sama lain. Mayoritas lingkup TA mencakup papan tulis atau lembar-lembar kertas berukuran besar yang dapat digunakan trapis maupun klien untuk mengilustrasikan berbagai transaksi dan permainan dan soalsoal penting lainnya. Sebagian trapis menggunakan alat bantu audio-visual untuk memberikan umpan-balik dan mempertinggi kesadaran.

Beberapa bentuk diagnosis bisa digunakan untuk menafsir sifat masalah.Klien berpartisipasi secara aktif dalam diagnosis dan penafsiranpenafsiran, dan diajari membuat penafsiran dan penilaian-penilaian.Konfrontasi sering digunakan, dan kontrak-kontrak dianggap penting, dan bertanya adalah bagian dasar dari AT. Ada dua teknik yang bisa diterapkan yaitu: (1) Teknik Dorongan Minimal (Minimal Encouragement) (2) Teknik mengarahkan (Directing) (Khairani, 2014: 72). Menurut Skinner dalam Dimyati Mahmud (1989: 123), tingkah laku bukanlah sekedar respon terhadap stimulus, tetapi suatu tindakan yang disengaja atau operan. Operan ini dipengaruhin oleh apa yang terjadi sesudahnya. Jadi operan conditioning atau operan learning itu melibatkan pengendalian konsekuensi.

\section{METODE PENELITIAN}

Pendekatan yang digunakan adalah pendekatan eksperimen dengan subjek tunggal (SSQD). Menurut DeMario dan Crowle (Sunanto dkk 2005: 55) desain pada bidang modifikasi perilaku dengan eksperimen kasus tunggal secara garis besar ada dua katogori yaitu: Desain reversal dan disain multiple baseline cross terdiri dari empat macam, yaitu: desain $A-B$, desain A-B-A, desain A-B-A-B. Penelitian ini menggunakan menggunakan desain A-B-A. Pada desain A-B-A peneliti melakukan replikasi (pengulangan) pengukuran dimana fase baseline (A1) fase intervensi (B) baseline yang kedua (A2) hanya dua kali untuk subyek yang sama. Dengan kata lain ada pengukuran ulang pada fase baseline tapi tidak dengan fase intervensi. Partisipan penelitian ini adalah seorang siswa yang memiliki hubungan social rendah yang diperkirakan dapat menghambat proses belajar untuk mencapai prestasi akademik dan non akademik di sekolah (tehnik purposif). (Sugiyono, 2009: 85) Siswa yang dipilih sebagai subjek penelitian ini, merupakan hasil dari analisis dari penyebaran angket sosiometri. Analisis data penelitian dilakukan secara kuantitatif dan kualitatif. Analisis kuantatif menggunakan analisis perolehan hasil angket, sedangkan analisis kualitatif meliputi reduksi data, penyajian data, dan penarikan kesimpulan (miles dan huberman, dalam sofyan siregar, 2010: 213).

\section{HASIL DAN PEMBAHASAN}

Deskripsi hasil penelitian penjelaskan tentang kondisi terisolir yang dialami siswa setelah mendapatkan konseling AT yaitu 42 termasuk kategori sedikit terisolir, karena skornnya berada pada rentang $35 \mathrm{~s} / \mathrm{d} 50$. 
Tabel 4.5

Data Skor Kondisi Klien yang terisolir karena egois Setelah Mendapat

\begin{tabular}{|c|c|c|c|c|}
\hline \multicolumn{5}{|c|}{ Treatment } \\
\hline No. & \begin{tabular}{|c|}
$\begin{array}{c}\text { Aspek- } \\
\text { aspek }\end{array}$ \\
\end{tabular} & $\begin{array}{c}\text { Jumlah } \\
\text { skor }\end{array}$ & Prosen (\%) & kategori \\
\hline 1 & $\begin{array}{c}\text { Isolate } \\
\text { voluntary }\end{array}$ & 20 & $50 \%$ & \\
\hline 2 & $\begin{array}{c}\text { Isolate } \\
\text { involuntary }\end{array}$ & 22 & $55 \%$ & \\
\hline \multicolumn{2}{|c|}{ Rata-rata Skor } & 2,05 & & \\
\hline
\end{tabular}

Untuk lebih memahami makna skor-skor kondisis klien setelah mendapat treatment, di bawah ini dibuat grafiknya sebagai berikut:

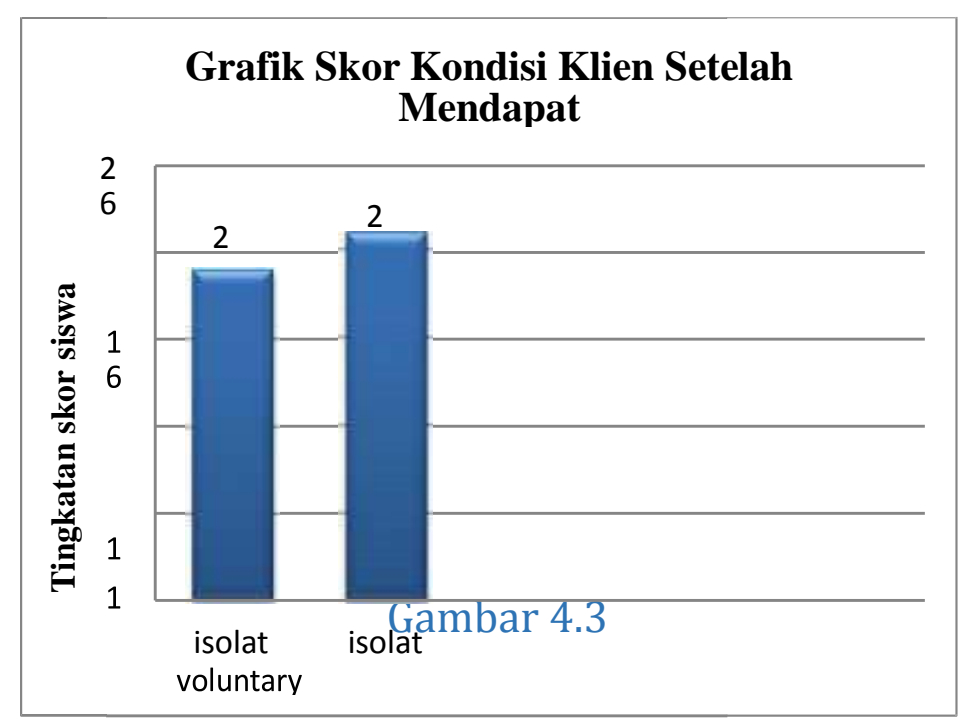

Grafik Skor Kondisi Klien Setelah Mendapat Treatment Layanan Konseling

Berdasarkan tabel 4.5 dan gambar 4.3 di atas dapat dipahami bahwa tingkat keterisoliran Siswa pada:

1. Aspek voluntary termasuk kategori tidak terisolir karena skornya sebesar 20 berada pada rentangan antara $20 \mathrm{~s} / \mathrm{d}<35$

2. Aspek isolate involuntary termasuk kategori tidak terisolir karena skornya sebesar 22 berada pada rentangan $20 \mathrm{~s} / \mathrm{d}<35$

\section{Secara Spesifik Pada Perilaku Klien}

Kondisi perilaku spesifik klien setelah mendapat treatment konseling individual adalah sebagaimana tercantum pada grafik di bawah ini: 


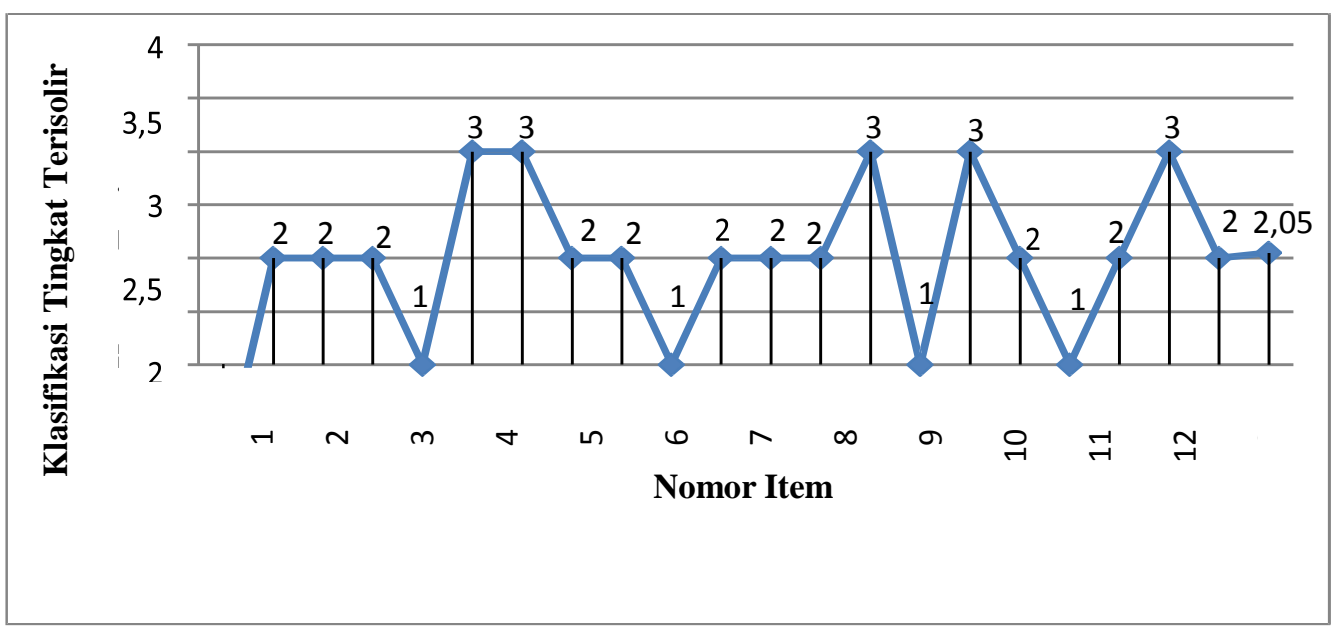

Gambar 4.4

Grafik skor kondisi spesifik klien setelah mendapat treatment konseling individual

Berdasarkan gambar 4.4 di atas, dapat diketahui bahwa kondisi prilaku spesifik klien setelah mendapat pelayanan konseling individual ternyata dapat meningkat kearah yang lebih baik, dengan rata-rata skor sebesar 2,05.

a. Perbandingan Kondisi Klien Sebelum dan Sesudah Mendapat Treatment Layanan Konseling

Data skor kondisi klien sebelum dan setelah mendapatkan treatment pada aspekaspek keterisoliran siswa adalah sebagai berikut:

\section{Tabel 4.7}

Data perbandingan skor berdasarkan aspek-aspek terisolir karena egois

\begin{tabular}{|c|c|c|c|c|c|c|c|}
\hline \multirow{2}{*}{ No. } & \multirow{2}{*}{$\begin{array}{l}\text { Aspek- } \\
\text { Aspek } \\
\text { Katerisolira }\end{array}$} & \multicolumn{2}{|c|}{$\begin{array}{l}\text { Sebelum } \\
\text { treatme }\end{array}$} & \multicolumn{2}{|c|}{$\begin{array}{l}\text { Sesudah } \\
\text { treatme }\end{array}$} & \multicolumn{2}{|c|}{ Perbedaan } \\
\hline & & $\begin{array}{r}\text { Sk } \\
\mathbf{0}\end{array}$ & $\%$ & Skor & $\%$ & Skor & $\%$ \\
\hline 1 & $\begin{array}{l}\text { Isolate } \\
\text { voluntar }\end{array}$ & 31 & 77,5 & 20 & 50 & 11 & 27,5 \\
\hline 2 & $\begin{array}{l}\text { Isolate } \\
\text { involutar }\end{array}$ & 24 & 60 & 22 & 55 & 2 & 5 \\
\hline & kategori & \multicolumn{2}{|c|}{ Terisolir } & \multicolumn{2}{|c|}{$\begin{array}{c}\text { Sedikit } \\
\text { terisoli }\end{array}$} & - & - \\
\hline
\end{tabular}

Untuk lebih memahami makna perbandingan data skor kondisi klien sebelum dan sesudah dilakukan treatment konseling individual pada tabel 4.7 di atas, di bawah ini dibuat grafiknya sebagai berikut: 


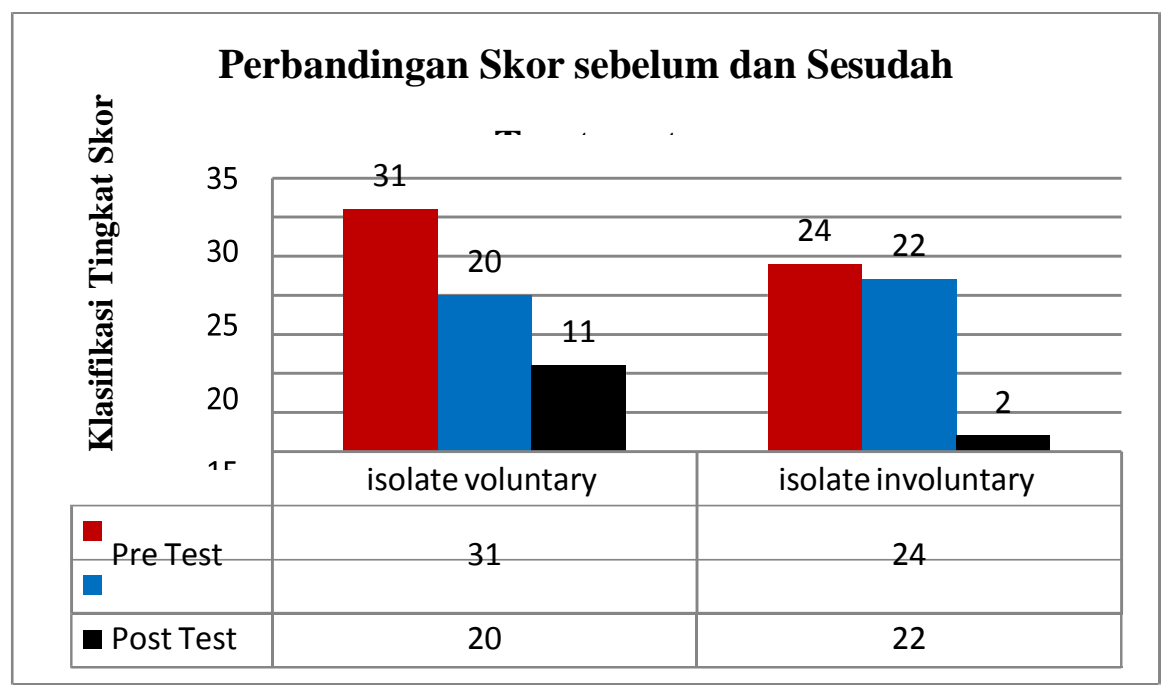

Grafik Perbandingan Skor Klien Yang Terisolir Karena Egois Sebelum dan Sesudah Dilakukan Treatment Konseling Individual di MA Nurul Iman tahun pelajaran $2017 / 2018$.

Berdasarkan tabel 4.7 dan gambar 4.5 di atas dapat dipahami bahwa tingkat keterisoliran sebelum dan sesudah treatment adalah sebagai berikut: Jika dilihat dari aspek-aspek keterisoliran klien yang paling menonjol sebelum treatment konseling individual adalah aspek isolate voluntary yang cenderung terisolir dengan skor 31 (77,5\%), yang termasuk kategori terisolir, setelah treatment meningkat kearah yang lebih baik dengan skor 20 (50\%) yang termasuk dalam kategori sedikit terisolir. Hal ini berarti adanya pemahaman dari klien tentang pentingnya bersosial dan menghargai orang lain dan mengerti tentang dampak dari sikap egois jika dibiarkan akan dapat merugikan diri sendiri maupun orang lain.

\section{Profil masalah siswa yang terisolir karena egois}

Data awal hasil penelitian ditemukan profil siswa yang terisolir karena egois diantaranya: (1) Subyek hanya mau berkelompok dengan teman yang lebih pintar saja. (2) Subyek tidak mau mengerjakan tugas secara berkelompok. (3) Subyek hanya mau menang sendiri dan selalu memaksakan kehendak agar pendapatnya diterima. (4) Subyek tidak mau menghargai teman yang sedang berbicara saat sedang berlangsungnya diskusi. (5) Subyek sering merasa iri melihat temannya yang berprestasi. (6) Subyek sering menyalahkan dan mengkritik teman.

Berdasarkan dari hasil penelitian ini, ditemukan beberapa faktor yang mengakibatkan siswa menjadi egois sehingga siswa menjadi terisolir. Adapun faktor yang ditemukan oleh peneliti yaitu pola asuh orang tua yang terbiasa memanjakan anaknya, sehingga anak menjadi egois karena sering dimanjakan dan dituruti keinginannya, yang menyebabkan anak menjadi idividu yang tidak bisa menghargai orang lain. Jadi pola asuh orang tua sangat berpengaruh terhadap 
perkembangan individu.

Hasil uraian di atas tentang profil siswa terisolir karena egois tidak jauh berbeda dengan pendapat Hurlock (1980: 217) tentang ciri-ciri anak yang terisolir karena egois yaitu: (1) Penampilan diri yang kurang menarik. (2) Kurang sportif. (3) Perilaku yang menonjolkan diri, mengganggu orang lain, suka memerintah, tidak bekerja sama dan kurang bijaksana. (4) Kurangnya kematangan terutama dalam hal pengendalian emosi, ketenangan, kepercayaan diri, dan kebijaksanaan. (5) Mementingkan diri sendiri dan cepat marah. Kondisi karakter siswa di atas perlu diberikan layanan koseling.

\section{Pengaruh Konseling Analisis Transaksional Dalam Mengatasi Masalah Siswa Yang Teisolir Karena Egois}

Dari hasil penelitian ditemukan adanya perubahan subyek setelah mendapatkan treatment layanan konseling individual, subyek menyadari bahwa kebiasaannya itu tidak baik dan subyek bersedia untuk merubah kebiasaannya tersebut. Hal ini sesuai dengan tujuan dari konseling Analisis Transaksional yaitu mempermudah subyek dalam berhubungan antar perorangan serta terampil dalam menentukan keputusan. Sesuai dengan pendapat George dan Kristiani tentang tujuan utama dari konseling Analisis Transasional, yaitu: (1) memfasilitasi perubahan perilaku. (2) meningkatkan keterampilan untuk menghadapi sesuatu. (3) meningkatkan kemampuan dalam menentukan keputusan. (4) meningkatkan hubugan antar perorangan. (5) menyediakan fasilitas untuk pengembangan kemampuan klien.

Konseling dengan teknik Analisis Transaksional memang mampu menyadarkan klien akan kebiasaannya yang membuat dirinya menjadi terisolir serta dapat merubah sedikit kondisi klien dari terisolir menjadi sedikit terisolir. Hal ini tidak lepas dari kelemahan konseling dengan teknik Analisis Transaksional yaitu kurang efisien terhadap kontrak treatment. Analisis Transaksional mengharapkan kontrak treatment antara konselor dengan klien, harus terjadi antara status ego dewasa. Artinya menghendaki bahwa klien mengikat kontrak secara realistis, sebagai orang yang membutuhkan pertolongan. Tetapi dalam kenyataannya ditemukan bahwa klien tidak menyadari kesalahannya dan merasa tidak memerlukan pertolongan, sehingga memerlukan beberapa kali pertemuan untuk mengungkap masalah yang sedang dialami klien. Sesuai dengan pendapat Eric Berne menyatakan bahwa Analisis Transaksional melibatkan suatu kontrak yang dibuat oleh klien, yang dengan jelas menyatakan tujuan-tujuan dan arah proses konseling.

\section{SIMPULAN}

Berdasarkan hasil penelitian dan pembahasan mengenai pengaruh konseling analisis Transaksional efektif dalam mengentaskan masalah siswa yang terisolir karena egois. Arah penelitian memberikan kontribusi dalam layanan bimbingan dan konseling diantaranya meningkatkan penelitian-penelitian yang berhubungan dengan teknik konseling. 


\section{DAFTAR PUSTAKA}

Corey, Gerald. (1988). Teori dan Praktek Konseling dan Prikoterapi. PT Eresco Prayitno. (2004). Layanan Bimbingan Kelompok dan konseling kelompok. Padang: Universitas Negeri Padang.

Hurlock, B. Elizabeth. (1980). Psikologi Perkembangan, Jakarta: Erlangga.

Khairani, Makmun. (2014). Psikologi Konseling. Yogyakarta.

CV. Aswajapressindo

Latipun, 2001. Psikologi konseling, Malang: UMM Press

Mahmud, M. dimyati. (1989). Psikologi Pendidikan. Jakarta: Depdikbud.

Siregar, Sofyan. (2010). Statistika Deskriptif untuk penelitian. Jakarta: PT RajaGrafindo Persada

Sugiyono. (2009). Metode Penelitian kuantitatif Kualitatif dan R \& D. Bandung: Alfabeta.

Sunarya, yaya (2005). Beberapa Karakteristik Siswa Terisolir (Jurnal Psikologi Pendidikan dan Bimbingan vol. 1-3)

Sunanto, J. et.al. (2006). Penelitian dengan subjek tunggal. Bandung: UPI Press 